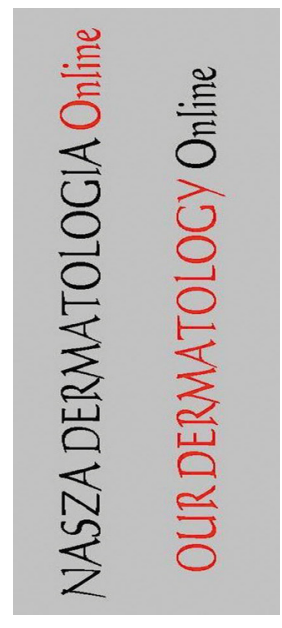

\title{
PLASMA CELL BALANITIS (ZOON'S BALANITIS): A CLINICOPATHOLOGICAL STUDY OF 8 CASES
} PLAZMAKOMÓRKOWE ZAPALENIE ŻOŁĘDZI (ZAPALENIE ŻOŁĘDZI ZOONA): KLINICZNO-PATOLOGICZNE BADANIE 8 PRZYPADKÓW

\author{
P. V. Krishna Rao ${ }^{1}$, Hari Kishan Kumar Yadalla ${ }^{2}$ \\ ${ }^{1}$ Andhra Medical College, Visakhapatnam, Andhra Pradesh, India \\ ${ }^{2}$ M.V.J. Medical College \& Research Hospital, Hoskote, Bangalore, India
}

Corresponding author: Dr. P.V. Krishna Rao

drkrishna1986@yahoo.co.in

\begin{abstract}
A disorder first described by Zoon in 1952, Zoon`s balanitis or Plasma cell balanitis (PCB), is an uncommon clinical disorder seen in middleaged uncircumcised men. It is characterized by one or more indolent well demarcated, glazed, reddish brown patches on the glans penis or prepuce. The etiology of this disease is unknown. This balanitis does not respond to routine topical antifungals, steroid creams and systemic antifungals. Diagnosis is confirmed by biopsy. Herein we report 8 cases of PCB, presenting with a characteristic clinical picture of the disease. In all cases circumcision was done and histopathology confirmed the diagnosis of PCB. All patients were followed up for a period of 6 months and no recurrences were observed. Development of malignancy is not seen. In conclusion. We believe that for all cases of balanitis, not responding to routine topical antifungals, steroid creams and systemic antifungals, the diagnosis of Zoon's balanitis should be considered.
\end{abstract}

\section{Streszczenie}

Choroba po raz pierwszy została opisana przez Zoon’a w 1952 roku. Zapalenie żołędzi typu Zoona lub też plazmacytowe zapalenie żołędzi (PCB) jest rzadkim, klinicznym zaburzeniem obserwowanym u nieobrzezanych mężczyzn w średnim wieku. Charakteryzuje się ono jedną lub większą ilością łagodnych, dobrze odgraniczonych, połyskujących, czerwonawych plamek na żołędzi penisa lub napletku. Etiologia zmian pozostaje nieznana. Ten rodzaj zapalenia żołędzi nie odpowiada na typowe leczenie przeciwgrzybicze: miejscowe czy systemowe oraz na maści sterydowe. Diagnoza jest potwierdzana biopsją. W tym artykule opisujemy 8 przypadków PCB oraz ich obraz kliniczny. We wszystkich przypadkach został wykonany zabieg obrzezania a badanie histopatologiczne potwierdziło diagnozę. Wszyscy pacjenci byli obserwowani przez okres 6 miesięcy, nie zanotowano nawrotu choroby. Nie zanotowano transformacji nowotworowej. Wszystkie przypadki zapalenia żołędzi nie odpowiadające na leczenie przeciwgrzybicze miejscowe lub systemowe oraz na maści sterydowe powinny zostać ponownie rozpatrzone pod kątem diagnozy PCB.

Key words: plasma cell balanitis; Zoon`s balanitis; circumcision

Słowa klucze: zapalenie plazmakomórkowe żołędzi; zapalenie żołędzi Zoona; obrzezanie

\section{Introduction}

In 1952, J.J. Zoon first recognized balanitis circumscripta plasmacellularis or plasma cell balanitis (PCB), which is now recognized as an idiopathic, rare, benign penile dermatosis. It is important to distinguish this benign condition from the clinically similar neoplastic Erythroplasia of Queyrat. PCB affects males, but analogous lesions sharing both clinical and histologic features of PCB have been reported in women as vulvitis circumscripta plasmacellularis. PCB is most common in middle-aged to older men, with cases reported in patients aged 20-88 years. The patient, a male of middle age or older, usually presents with a characteristic plaque on the glans penis or prepuce, present for an average of 1-2 years before diagnosis. Symptoms are minimal, but patients may complain of mild pruritus or tenderness. Some patients present for evaluation because of cosmetic concerns or anxiety [1-5].

Here, we report 8 such cases since very few studies are available on Zoon's balanitis. This work has been initiated, to study the presenting characteristic clinical and histopathological features of PCB, the importance of histology in differentiating from similarly presenting malignant lesion Erythroplasia of Querat (Squamous cell carcinoma in-situ) and to evaluate the treatment response and follow-up for any recurrences.

\section{Case reports}

8 cases of chronic recurrent balanitis in uncircumcised men aged 25, 28, 31, 41, 45, 49, 52 \& 60 years were studied. 5 were married and 3 were unmarried. The mean duration of balanitis in these 8 cases was 7 months shown in (Tab. I). 
There was no history of exposure to sexually transmitted infections, diabetes or urethral symptoms. The first patient gave a history of application of soframycin cream. Examination of these patients showed erythematous plaque over glans penis in six of them and in two, lesions extended onto prepuce (Fig. 1,2).

These cases were treated with topical and systemic antifungals and also with mild corticosteroid cream for 3 months with no response. In one case topical tacrolimus $0.03 \%$ application cleared the lesions but recurrence was seen within 3 months.
In all cases, circumcision was performed and a biopsy was sent for histopathological examination. Results indiucated that the features of these were consistent with Plasma cell balanitis (Fig. 3,3a,4). These cases were followed-up for 6 months and no relapses were observed.opthamologist. Assessment of diabetic neuropathy was done on the basis of the criteria detailed by Foster [7]. Relevant microbiological and histopathological investigations were carried out to confirm the clinical diagnosis.

\begin{tabular}{|l|l|l|l|l|}
\hline Case & Age & Duration & Clinical feartures & Treatment \\
\hline 1 & $25 y r s$ & 3 months & Asymptomatic erythematous plaque - penis & Circumcision \\
\hline 2 & $28 y r s$ & 5 months & Asymptomatic erythematous plaque - penis & Circumcision \\
\hline 3 & $31 \mathrm{yrs}$ & 6 months & $\begin{array}{l}\text { Itchy erythematous plaque - penis extending } \\
\text { onto prepuce }\end{array}$ & Circumcision \\
\hline 4 & $41 \mathrm{yrs}$ & 8 months & Asymptomatic erythematous plaque - penis & Circumcision \\
\hline 5 & $45 y \mathrm{ys}$ & 10 months & Asymptomatic erythematous plaque - penis & Circumcision \\
\hline 6 & $49 y r s$ & 4 months & $\begin{array}{l}\text { Asymptomatic erythematous plaque - penis } \\
\text { extending onto prepuce }\end{array}$ & Circumcision \\
\hline 7 & $52 \mathrm{yrs}$ & 8 months & Asymptomatic erythematous plaque - penis & Circumcision \\
\hline 8 & $60 y r s$ & 12 months & Erythematous plaque - penis with burning & Circumcision \\
\hline
\end{tabular}

Table I. Cases of plasma cell balanitis

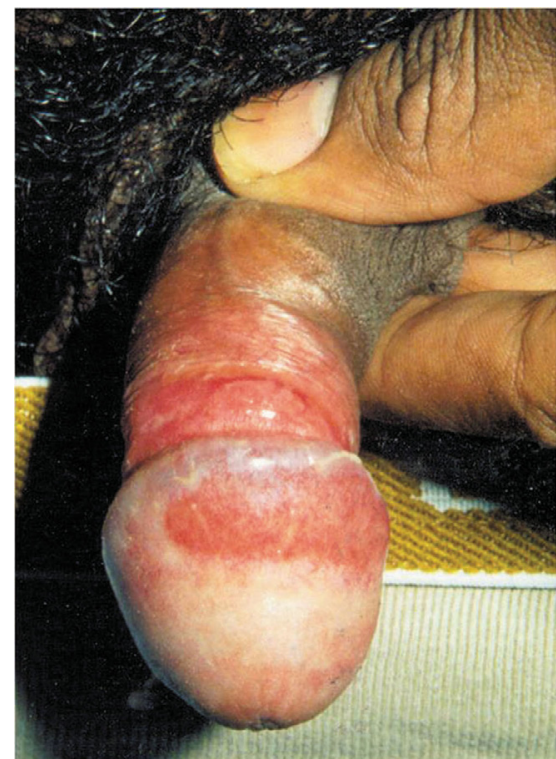

Figure 1. Erythematous plaque over penis extending onto prepuce

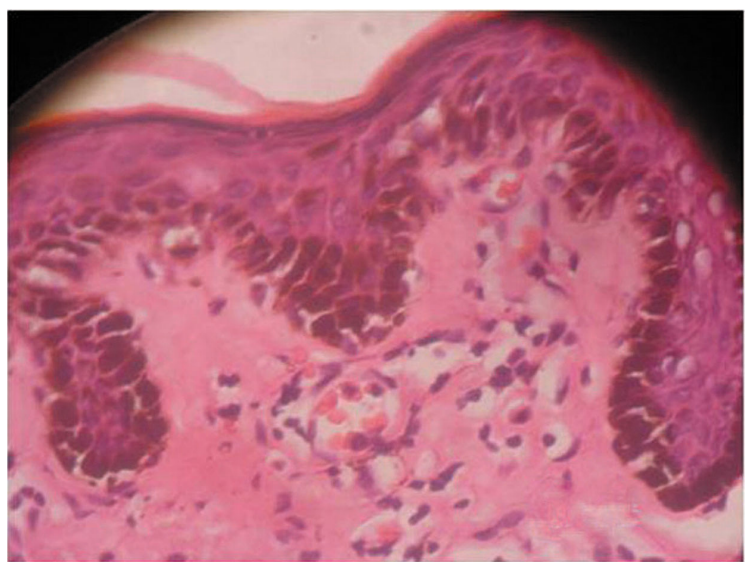

Figure 3. Attenuated epidermis containing lozenge shaped keratinocytes with dense dermal infiltrate rich in plasma cells (H\&E x 40)

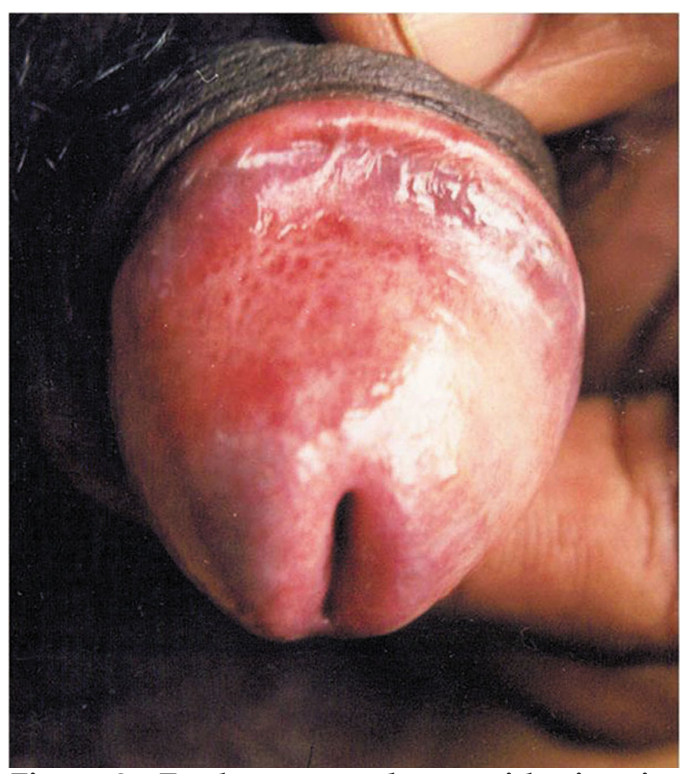

Figure 2. Erythematous plaque with pinpoint purpuric (cayenne pepper) spotting over penis

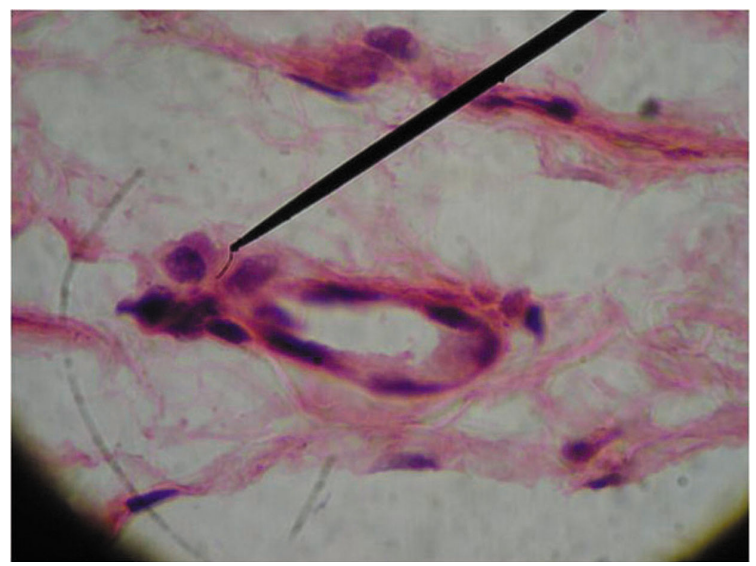

Figure 3a. Photomicrograph showing plasma cell infiltrate, dilated capillary and extravasated RBCs in upper dermis (H\&E $x$ 100) 


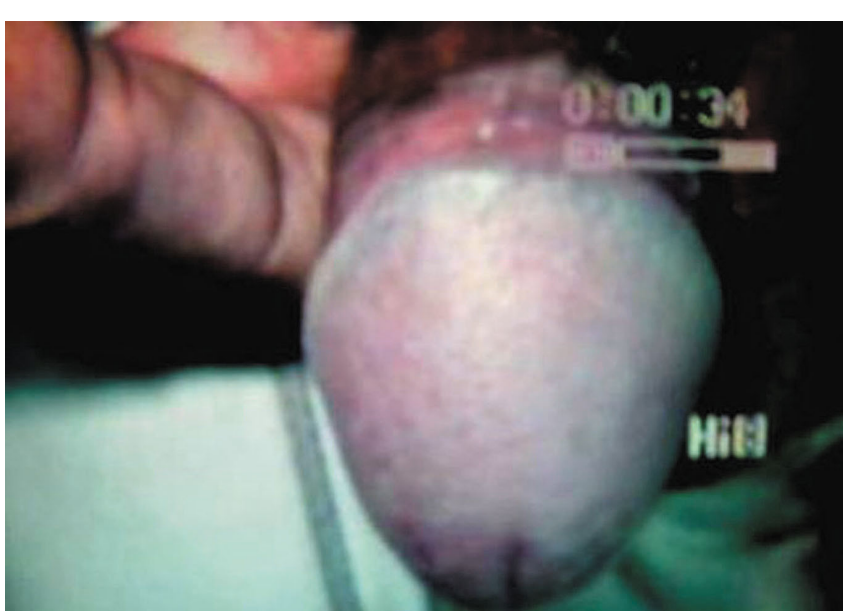

Figure 4. After circumcision, complete clearance of lesion

\section{Discussion}

Plasma Cell balanitis (PCB) or "balanitis circumscripta plasma cellularis" is a benign, idiopathic condition first recognized by Zoon in 1952. Zoon described eight cases of chronic balanitis with unique benign appearing histologic findings previously diagnosed as Erythroplasia of Queyrat [1-3].

Plasma cell balanitis typically presents as a solitary, smooth, shiny, red-orange plaque on the glans and or the prepuce of an uncircumcised, middle-aged to older man. The lesion often exhibits pinpoint purpuric cayenne pepper surface spotting with a yellow hue. Vegetative, erosive variants and multiple lesions have been reported [4]. PCB tends to be chronic and is often present for months to years before the patient reports for consultation. Symptoms are minimal, but may include mild tenderness or pruritus. Diagnosis is confirmed by the distinctive histologic findings. Epidermal atrophy with complete effacement of the rete ridges is present. Ulceration may occur. Suprabasal keratinocytes are diamond shaped which are also called "lozenge keratinocytes" are common with uniform intercellular spaces termed "watery spongiosis". A dense lichenoid subepidermal infiltrate composed largely of plasma cells is characteristic. Erythrocyte extravasation and hemosiderin deposition are often noted [5-9].

The cause of PCB is unclear. All confirmed cases have involved uncircumcised men. Heat, friction, poor hygiene, chronic infection with Mycobacterium smegmatis, trauma, response to an unknown exogenous agent, immediate hypersensitivity response to $\operatorname{IgE}$ class antibodies and hypospadiasis have been implicated as predisposing factors. A viral cause of PCB has been rejected after both PCR and electron microscopy failed to show evidence of viral particles in PCB lesions. Kossard et al postulated a causal relation between certain PCB variants and lichen aureus, in the light of similar vascular fragility and histologic abnormalities [4].

The treatment of choice for PCB is circumcision $[4,5,10,11]$. Successful ablation of PCB has been achieved with carbondioxide laser and Erbium:YAG laser [12,13]. Successful treatment of vulvar anologue of PCB with intralesional interferon $\alpha$ has also been reported. Treatment with topical agents including corticosteroids and antifungals cause mild improvement, but the lesion usually recurs following discontinuation of treatment and are generally not curative $[3,4,16]$. Petersen et al found topical fusidic acid $2 \%$ cream to be beneficial [14]. Chander etal used topical tacrolimus $0.03 \%$ with success [15]. Griseofulvin has been tried without success.

This case series is being reported to make the treating clinicians aware of the clinical and histopathological features of this uncommon balanitis, and to emphasize the importance of histopathology in distinguishing this benign condition from similar looking malignant conditions and the treatment response.

\section{REFERENCES}

1. Edwards S: Balanitis and balanoposthitis: a review. Genitourin Med 1996: 72: 155-159.

2. English JC 3rd, Laws RA, Keough GC, Wilde JL, Foley JP, Elston DM: Dermatoses of glans penis and prepuce. J Am Acad Dermatol 1997; 37: 1-24.

3. Mikhail GR: Cancers, precancers and pseudocancers on the male genitalia: A review of clinical appearances, histopathology, and management. J Dermatol Surg Oncol 1980; 6: 1027.

4. Jolly BB, Krishnamurty S, Vaidyanathan S: Zoon`s balanitis. Urol Int 1993; 50: 182-184.

5. Kumar B, Sharma R, Ragagopalan M, Radotra BD: Plasma cell balanitis: clinical and histological features- response to circumcision. Genitourin Med 1995; 71: 32-34.

6. Arumainayagam JT, Sumathipala AHT: Value of performing biopsies in genitourinary clinics. Genitourinary Medicine 1990; 66: 407.

7. Pastar Z, Rados J, Lipozencić J, Skerlev M, Loncarić D: Zoon plasma cell balanitis: an overview and role of histopathology. Acta Dermatovenerol Croat. 2004; 12: 268-273.

8. Weyers W, Ende Y, Schalla W, Diaz-Cascajo C: Balanitis of Zoon: A clinicopathologic study of 45 cases. Am J Dermatopathol 2002; 24: 459-467.

9. Balato N, Scalvenzi M, La Bella S, Di Costanzo L: Zoon's Balanitis: Benign or Premalignant Lesion? Case Rep Dermatol. 2009; 1: 7-10.

10. Fernandiz C, Ribera M: Zoon's balanitis treated by circumcision. J Dermatol Surg Oncol 1984; 10: 622-625.

11. Mallon E, Hawkins D, Dinneen M, Francics N, Fearfield L, Newson R, et al: Circumcision and genital dermatoses. Arch Dermatol 2000; 136: 350-354.

12. Baldwin HE, Geronemus RG: The treatment of Zoon's balanitis with the carbon dioxide laser. J Dermatol Surg Oncol 1989; 15: 491-494.

13. Albertini JG, Holck DE, Farley MF; Zoon's balanitis treated with Erbium:YAG laser ablation. Lasers Surg Med 2002; 30: 123-126.

14. Petersen CS, Thomsen K; Fusidic acid cream in the treatment of plasma cell balanitis. J Am Acad Dermatol 1992; 27: 633-634.

15. Chander R, Garg T, Kakkar S, Mittal S: Treatment of balanitis of Zoon's with tacrolimus $0.03 \%$ ointment. Indian J Sex Transm Dis 2009; 30: 56-57.

16. Hota D, Basu R, Senapati R: Zoon's balanitis - diagnosis and follow-up. Indian J Urol 2002; 18: 173-175.

Copyright by P.V. Krishna Rao et al. This is an open access article distributed under the terms of the Creative Commons Attribution License, which permits unrestricted use, distribution, and reproduction in any medium, provided the original author and source are credited. 